\title{
CEO Gender, Government Ownership, and Firm Performance: Evidence from China
}

Hanchen $\mathrm{Li}^{*}$ Xiaochuan Tong ${ }^{* *}$

(Beijing Jiaotong University* University of Massachusetts Boston ${ }^{\star *}$ )

Presenter: Xiaochuan Tong

PhD Candidate, UMass Boston

xiaochuan.tong001@umb.edu

College of Management

University of Massachusetts Boston

American Accounting Association

Virtual Annual Meeting

CTLA Conference on Teaching and 


\section{Overview of the Content}

- Research Question

- Hypotheses

- Main Findings

- Why is Important?

- What We do?

- Discussion 


\section{Research Question}

\section{- Background:}

- This paper is motivated by the literature in the field of psychology and leadership, which focuses on the female leadership advantage (Eagly \& Carli, 2003).

- The idea of women are better managers is increasingly recognized and acknowledged by the popular press publications (Paustian-Underdahl et al., 2014).

- New York Times: "no doubts: women are better managers" (Smith, 2009).

- Daily Mail: (Women in top jobs are viewed as "better leaders" than men, 2010).

- Women merely hold $5.8 \%$ of the S\&P 500 CEO positions as of December 2019 (Women CEOs of the S\&P 500, 2020) 


\section{Research Question}

\section{- Background:}

- Whether there exists a female leadership advantage? In psychology and leadership literature (Cowen \& Montgomery, 2019; Eagly \& Carli, 2003a).

- Paustian-Underdahl et al. (2014) conclude that after all leadership contexts are considered, the perceived leadership effectiveness does not differ between men and women

- Through a systematic review of the psychology and leadership literature

- However, the on-average effectiveness view of female leadership is challenged for its simplicity.

- The psychology and leadership literature further suggests:

- It would make better sense to investigate when and why there is a gender difference in the leadership effectiveness (Eagly \& Carli, 2003a, 2003b; Vecchio, 2002) rather than whether there exists a gender difference. 


\section{Research Question}

\section{- Motivation:}

- However, there is a lack of evidence in literature with respect to when and why CEO gender matters, especially under different corporate governance conditions (i.e. ownership structures).

- Specifically, we investigate whether there exists a female leadership advantage under government ownership.

- Government ownership (e.g. state-owned enterprises (SOEs)) impacts females differently from males

- whether/how government ownership matters in terms the gender effect on firm performance?

\section{- Research Question:}

- What exactly is the joint impact of CEO gender and government ownership on firm performance?

- (In this paper, we call state-owned enterprises SOEs) 


\section{Research Question}

\section{- Literature:}

- Gender issues are an important topic in corporate governance (Adams \& Ferreira, 2009; Adler, 2001).

- Promoting women into executive positions is highly associated with the profitability of Fortune 500 firms (Adler, 2001).

- CEO gender appears to affect various aspects of firm performance and firm behavior:

- lower risk-taking, better survival, and less efficient capital allocation (Faccio, Marchica \& Mura, 2016);

- The Efficiency of government ownership remains unresolved.

- Inefficient View: (compared to private ownership): Boycko, Shleifer \& Vishny (1996); Dewenter \& Malatesta (2001); Porta, Lopez-de-Silanes \& Shleifer (2002); Chen \& Qian (1998)

- Efficient View: Caves \& Christensen (1980), Kay \& Thompson (1986), Wortzel \& Wortzel (1989), Martin \& Parker (1995) and Kole and Mulherin (1997) 


\section{Hypothesis Development}

- We predict a positive relationship between female CEOs and firm performance under government ownership

- First, psychology and gender studies suggest that female CEOs are better at communication (Wood, Polek, \& Aiken, 1985; Eagly \& Carli, 2003; Schubert, 2006).

- political connections (Fan, Wong, \& Zhang, 2007) and political resources (Faccio, 2006)

- Second, prior literature suggests that the CEO turnover is less sensitive to firm performance in stateowned enterprises (SOEs) (Kato \& Long, 2006).

- This provides CEOs in SOEs with a less competitive environment, which is particularly good for female CEOs as women tend to shy away from competition (Niederle \& Vesterlund, 2007).

- Third, working in government-owned enterprises is in general considered to be more stable, less pressured, and better respected in society. (Unger \& Chan (1995); Nolan \& Xiaoqiang (1999))

- For these reasons, the less competitive work environment is preferable to women (Niederle \& Vesterlund, 2007). 


\section{Main Findings}

\section{Female CEOs outperform male CEOs under government ownership}

- (In this paper, we call government/state-owned enterprises as SOEs.)

1. We show that firms with female CEOs and government ownership have significantly better performance.

2. The magnitude of this effect is much bigger in central state-owned enterprises (CSOEs) than that in local state-owned enterprises (LSOEs).

3. The mechanisms of the improved firm performance of female-CEO-run and state-owned enterprises (SOEs) are identified as increased profitability and operating efficiency. 


\section{Why Important?}

\section{- Female Leadership Advantage}

- We draw insights upon the literature on psychology and leadership, and extend the literature on the female leadership advantage in the context of corporate governance.

\section{- This study adds to several streams of literature:}

- Government Ownership

- Adds to the discussion on the impact of government ownership on its efficiency role (Bai et al., 2004; Boycko et al., 1996; La Porta et al., 2002) and its impact on firm performance and corporate governance.

- Gender issues in corporate governance

- Female CEOs outperformance male CEOs under specific conditions (i.e. government ow

- Corporate governance

- Efficiency of corporate governance 


\section{Why Important?}

- Implications:

- CEO-level:

- The implications of CEO gender of firm performance/accounting information - CEO performance (Faccio, Marchica \& Mura, 2016)

- Firm-level:

- Relevant to boards of directors to better incentivize both male and female CEOs corporate governance (Adams \& Ferreira, 2009)

- Government-level:

- Public policy making advice to the government

- Society-level:

- Underrepresentation of female in CEOs 


\section{What We Do?}

\section{- Research Question:}

- How does CEO gender matter under a government ownership structure in terms of firm performance?

\section{- Setting:}

- We exploit a powerful setting in the context of China, where there is a sufficient presence of government ownership and sufficient observations of firms run by female CEOs

- state-owned enterprises (SOEs), around 35\% to 20\% SOEs from 2005 to 2016 respectively)

- sufficient observations of firms run by female CEOs (around 5\% each year from 2005 to 2016).

- Data:

- We use data from CSMAR for the Chinese listed companies (2005-2016) 


\section{What We Do?}

\section{CEO Gender}

\begin{tabular}{cccc}
\hline $\begin{array}{c}\text { Report } \\
\text { Date }\end{array}$ & Female CEO & Male CEO & Female\% \\
\hline $12 / 31 / 2005$ & 57 & 1225 & $4.45 \%$ \\
$12 / 31 / 2006$ & 59 & 1276 & $4.42 \%$ \\
$12 / 31 / 2007$ & 74 & 1407 & $5.00 \%$ \\
$12 / 31 / 2008$ & 80 & 1464 & $5.18 \%$ \\
$12 / 31 / 2009$ & 92 & 1593 & $5.46 \%$ \\
$12 / 31 / 2010$ & 122 & 1931 & $5.94 \%$ \\
$12 / 31 / 2011$ & 136 & 2136 & $5.99 \%$ \\
$12 / 31 / 2012$ & 144 & 2242 & $6.04 \%$ \\
$12 / 31 / 2013$ & 137 & 2290 & $5.64 \%$ \\
$12 / 31 / 2014$ & 127 & 2385 & $5.06 \%$ \\
$12 / 31 / 2015$ & 128 & 2539 & $4.80 \%$ \\
$12 / 31 / 2016$ & 160 & 2803 & $5.40 \%$ \\
\hline
\end{tabular}

\section{Government Ownership}

- state-owned enterprises (SOEs)

\begin{tabular}{cccc}
\hline \multirow{2}{*}{ Year } & \multicolumn{3}{c}{$(1)$} \\
\cline { 2 - 4 } & SOE & non-SOE & SOE\% \\
\hline 2005 & 464 & 821 & $36.11 \%$ \\
2006 & 458 & 883 & $34.15 \%$ \\
2007 & 498 & 986 & $33.56 \%$ \\
2008 & 521 & 1,027 & $33.66 \%$ \\
2009 & 427 & 1,265 & $25.24 \%$ \\
2010 & 485 & 1,574 & $23.56 \%$ \\
2011 & 489 & 1,806 & $21.31 \%$ \\
2012 & 553 & 1,862 & $22.90 \%$ \\
2013 & 568 & 1,888 & $23.13 \%$ \\
2014 & 597 & 1,969 & $23.27 \%$ \\
2015 & 607 & 2,121 & $22.25 \%$ \\
2016 & 636 & 2,380 & $21.09 \%$ \\
Mean & & & $26.68 \%$ \\
Total & 6,303 & 18,582 & \\
\hline
\end{tabular}


- Firm Performance

\section{What We Do?}

Distribution of the F_SCORE

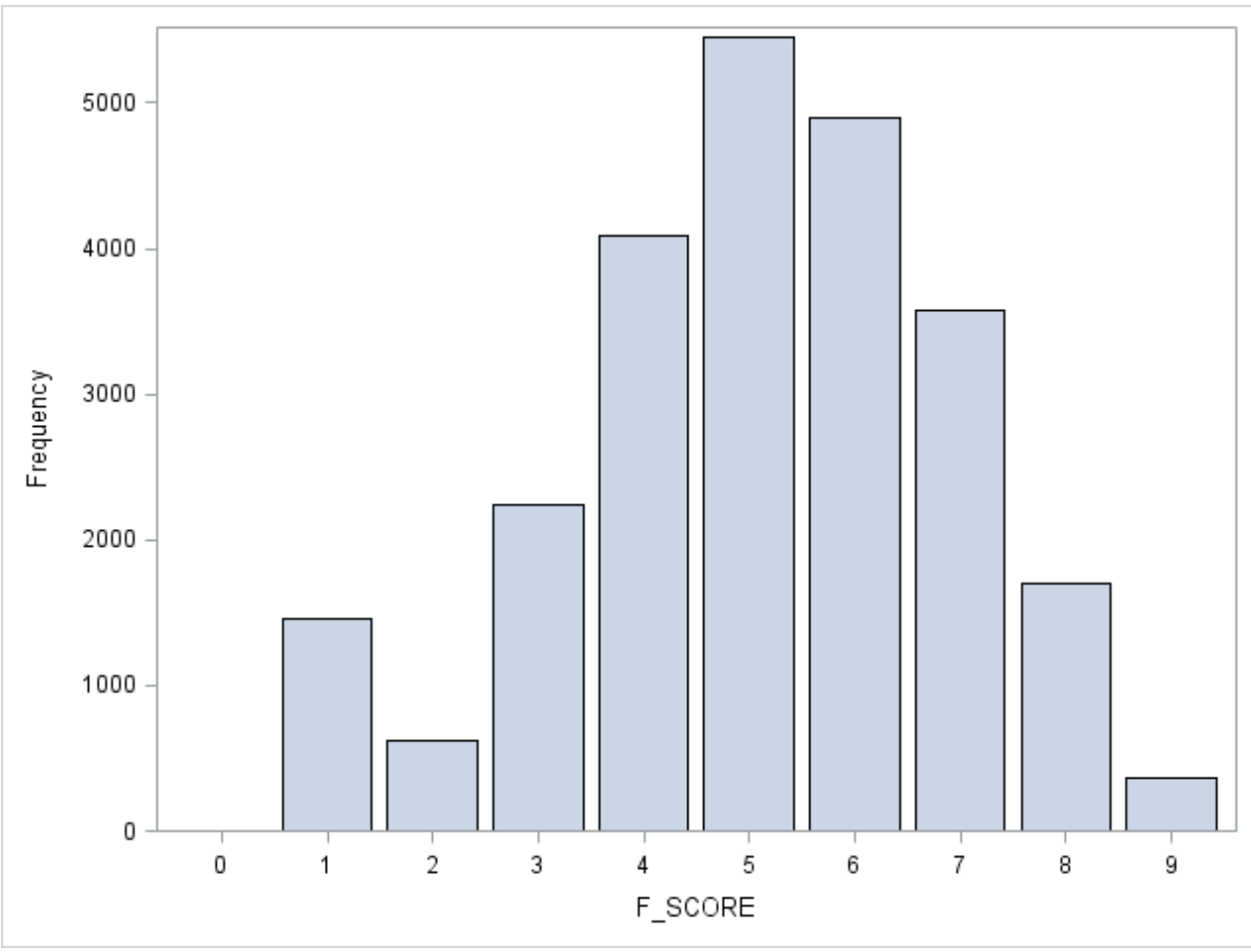

- Profitability

1. ROA (current year's net income before extraordinary items/beginning of the year total assets)

2. CFO (cash flow from operations/beginning of the year total assets)

3. $\triangle \mathrm{ROA}$ (current year's - prior year's)

4. ACCRUAL(equals 1 if $C F O>R O A$ )

- Capital Structure (to meet future debt obligations)

1. $\triangle$ LEVER (the historical change in the ratio of total long-term debt to average total assets)

2. $\triangle$ LIQUID (change in current ratio - current assets to current liabilities)

3. EQ_OFFER

- Operating Efficiency

1. $\triangle M A R G I N$ (change in current gross margin ratio)

2. $\triangle$ TURN (change in turnover ratio - total sales/beginning of the year total assets) 


\section{What We Do?}

- Baseline Model: (Faccio et al., 2016; Bae et al., 2019)

$$
\begin{aligned}
F_{-} S C O R E & =\beta_{1} \text { Female }+\beta_{2} S O E+\beta_{3} \text { Female }^{*} S O E \\
& +\beta_{4} \text { age }+\beta_{5} \text { degree }+\beta_{6} \log _{-} \text {totalSalary }+\beta_{7} C E O \_ \text {Duality } \\
& +\beta_{7} \text { firmsize }+\beta_{8} \operatorname{Ln}(1+\text { company's age })+\beta_{9} \text { asset-liability-ratio } \\
& +\gamma \Sigma \text { YearDum }+\delta \text { IndDum }+\varepsilon
\end{aligned}
$$

- Extended Model:

$$
S O E=C S O E+L S O E
$$


Table 7. Female CEOs and firm performance

\section{What We Do?}

Table 5. Female CEOs and firm performance in the full sample (SOEs)

\begin{tabular}{lc}
\hline Variable & Full samples \\
\hline Female CEO & -0.094 \\
SOE & $(0.254)$ \\
& $0.304^{* * * *}$ \\
Female CEO*SOE & $(0.000)$ \\
& $\mathbf{0 . 4 2 5}^{* * *}$ \\
Age & $(\mathbf{0 . 0 0 9 )}$ \\
& $0.425^{* * *}$ \\
Degree & $(0.009)$ \\
& -0.007 \\
Log (total salary) & $(0.622)$ \\
& $0.057^{* *}$ \\
CEO duality & $(0.015)$ \\
& $-0.307^{* * *}$ \\
Firm size & $(0.000)$ \\
& $0.123^{* * *}$ \\
Ln (1+company's age) & $(0.000)$ \\
& $0.161^{* * *}$ \\
Asset-liability ratio & $(0.000)$ \\
Number of observations & $0.908^{* * *}$ \\
Industry fixed effect & $(0.000)$ \\
Year fixed effect & 18,096 \\
\hline
\end{tabular}

in the full sample (CSEOs and LSOEs)

\begin{tabular}{lc}
\hline Variable & Full samples \\
\hline Female CEO & -0.094 \\
& $(0.254)$ \\
CSOE & $0.275^{* * *}$ \\
& $(0.000)$ \\
LSOE & $0.309^{* * *}$ \\
& $(0.000)$ \\
Female CEO*CSOE & $\mathbf{1 . 3 9 3} 3^{* * *}$ \\
& $(\mathbf{0 . 0 0 0 )}$ \\
Female CEO*LSOE & $\mathbf{0 . 3 3 5 ^ { * * * }}$ \\
& $(\mathbf{0 . 0 4 4 )}$ \\
Age & $0.008^{* * *}$ \\
& $(0.004)$ \\
Degree & -0.007 \\
& $(0.627)$ \\
Log (total salary) & $0.055^{* *}$ \\
& $(0.018)$ \\
CEO duality & $-0.310^{* * *}$ \\
& $(0.000)$ \\
Firm size & $0.124^{* * *}$ \\
& $(0.000)$ \\
Ln (1+company's age) & $0.908^{* * *}$ \\
Asset-liability ratio & $(0.000)$ \\
Number of observations & -0.050 \\
Industry fixed effect & $(0.538)$ \\
Year fixed effect & 18,096 \\
on & YES \\
& YES \\
\hline
\end{tabular}




\section{What We Do?}

\section{- Mechanisms}

- Profitability

- Operating Efficiency
Table 8. Female CEOs and Mechanisms of Improved Performance

\begin{tabular}{lccc}
\hline & $(1)$ & $(2)$ & $(3)$ \\
Variable & Profitability & Capital Structure & Operating \\
Efficiency
\end{tabular}




\section{What We Do?}

\section{- Additional Tests:}

- Propensity Score Matching (PSM):

- Address potential selection bias

- Matching non-SOEs with SOEs

- Heckman Selection Model:

- Potential non-random selection of the observations

- Analysis of Transition firms:

- Firms with CEO Gender Transitions

- Propensity Score Matching on Firms with CEO Gender Transitions 


\section{Discussion}

- Conclusion

- There is a female leadership advantage under a specific corporate governance setting (i.e. government ownership).

- Implications

- Female CEOs impact firm performance differently under different conditions

- Challenges the underrepresentation issue of female managers

- Government should improve the recruiting and promoting mechanisms for female CEOs

- Future Research

- In international settings

- Female CEOs under other conditions, besides government ownership

- A more detailed investigation on the evidence of the three possible explanations 


\section{Thank You!}

Presenter: Xiaochuan Tong PhD Candidate, UMass Boston

xiaochuan.tong001@umb.edu 